\title{
EFFECT OF STRAIGHT AND ANGLED ABUTMENTS ON THE STRAIN ON A ZIRCONIA CROWN AND IMPLANT IN THE MANDIBULAR SECOND MOLAR REGION: A FEA-BASED STUDY
}

\author{
VPLIV POKONČNIH IN POŠEVNIH OPORNIKOV NA \\ DEFORMACIJE CIRKONSKIH KRON IN VSADKOV V DRUGEM \\ MOLARNEM PODROČJU ČELJUSTI: ŠTUDIJA NA OSNOVI \\ METODE KONČNIH ELEMENTOV
}

\author{
Mahmut Sertac Ozdogan', Harun Gokce², Ismail Sahin ${ }^{3 *}$ \\ ${ }^{1}$ Ankara Yildirim Beyazit University, Faculty of Dentistry, Ankara, 06220, Turkey \\ ${ }^{2}$ TUBITAK Defence Industries Research and Development Institute, Ankara, 06261, Turkey \\ ${ }^{3}$ Gazi University, Technology Faculty, Department of Industrial Design Engineering, Ankara 06500, Turkey
}

Prejem rokopisa - received: 2019-06-07; sprejem za objavo - accepted for publication: 2019-09-30

doi:10.17222/mit.2019.121

\begin{abstract}
In a literature search no study evaluating implant-supported posterior restorations using zircon crowns with straight and angled abutments was found. In this study, the stress distribution of a zircon-crown restoration that will be prepared by using an angular and straight abutment in a mandibular second-molar deficiency, under functional forces, stress over zircon crown and environmental tissues of implant will be evaluated using the finite-element analysis (FEA) method. The FEA result showed that the use of straight implants contributes to the lowest stresses. The selection of a straight and angular abutment is very important for the balance of distributed loading.

Keywords: dental implant, zirconia, finite-element analysis
\end{abstract}

Avtorji članka v raziskavi že objavljene literature na to temo niso našli nobene študije, ki bi ovrednotila obnovo zob z vsadki, pri katerih so bile uporabljene cirkonske krone s pokončnimi ali poševnimi oporniki. V študiji avtorji analizirajo porazdelitev napetosti v obnovljeni cirkonski kroni, ki je bila stabilizirana z uporabo poševnih ali pokončnih opornikov v drugem molarnem segmentu čeljusti. S pomočjo metode končnih elementov (FEA, angl.: Finite Element Analysis), so pod obremenitvijo s funkcionalnimi silami ovrednotili nastale napetosti na cirkonskih kronah in v obdajajočem se tkivu (dlesnih). Rezultati FEA so pokazali, da uporaba pokončnih vsadkov povzroča manjše napetosti. Avtorji ugotavljajo še, da je pravilna izbira pokončnih ali poševnih opornikov zelo pomembna za uravnoteženo porazdelitev obremenitev.

Ključne besede: zobni vsadek, cirkonijev oksid, analiza na osnovi metode končnih elementov

\section{INTRODUCTION}

Dental epidemiological studies have shown that single teeth are common in all age groups. ${ }^{1}$ A single premolar or molar loss is considered to be a common cause of non-physiological occlusion resulting from the extrusion and overturning of adjacent teeth and counterteeth. ${ }^{2}$ For this reason, the continuity of an occlusion is important. It is controversial whether the missing second molars should be completed with a prosthetic treatment. ${ }^{3-5}$ For the second mandibular deficiency, there are several restorative options for a prosthodontic treatment. A fixed, partial cantilever prosthesis does not appear to be a preferred treatment, since they have produced undesirable biomechanical results, and removable partial prostheses could provide disturbing function and use. ${ }^{6}$ Inspite of these arguments, the negative consequences of failing to compensate for the

*Corresponding author's e-mail:

isahin@gazi.edu.tr (Ismail Sahin) mandibular second molars could be the deterioration of a balanced occlusion, overeruption of the contralateral tooth, and the incompatibility of the chewing system, in favor of compensating the missing second molars with a prosthesis. ${ }^{7}$ As a result, the use of single implants for second-molar restoration seems to be a preferred treatment. The use of dental implants in cases of partial toothlessness has been accepted as a modern clinical method with long-term success. ${ }^{8}$ In order to achieve this success, technical and biomechanical decisions must be made carefully. ${ }^{9}$

As a result of a study conducted by M. S. Kim et al., ${ }^{10}$ more than $90 \%$ of patients stated that they were functionally satisfied with a second-molar single-implant treatment. These findings suggest that a second-molar single implant can increase the chewing function. The ultimate goal of the implant treatment is that it is functional, aesthetic and easily applicable. ${ }^{11,12}$ For this purpose a correct implant placement is essential. Precise radiographic images of the potential recipient sites and 
appropriate surgical guidelines are necessary to place the implants in their predetermined positions. ${ }^{13}$ The implant placement is usually not ideal due to the morphology of the existing bone. One solution to this clinical problem is to use angled abutments. ${ }^{14}$

The anatomy of the jaws and the morphology of the edentulous crest determine the orientation and angle of the implant placement. Similarly, the position and morphology of the teeth are determined by aesthetic and functional considerations. In most cases there is a difference between the long axis of the implant and the long axis of the planned dental implant. The main factor leading to long-term failure in implant-supported restorations is the lack of understanding of biomechanical concepts. ${ }^{15}$

Ideally, the implants should be positioned parallel to the adjacent teeth and aligned vertically with the axial forces. However, it may not be possible for anatomical reasons. The mandibular canal position, crest anatomy, proximity to sinuses are other factors that can affect implant placement. ${ }^{16-18}$

The angle of the abutment used for the prosthetic restoration is one of the important factors affecting the stress distribution in the implant bone interface. Studies show that the use of angled abutments can cause a stress reduction. K. Tian et al. ${ }^{19}$ who examined the tension in tissues surrounding the implant with the use of angled abutments on one-unit dental implants in their FEA study, reported that the use of angled abutments reduced the stresses and showed a better stress distribution at the implant-bone interface. On the other hand, N. L. Clelland et al. ${ }^{20}$ in their study using photoelastic stress analysis reported that angled and straight abutments cause an increased stress in the bone and prosthesis, but this is within the physiological limits.

N. T. Inijan et al. ${ }^{21}$ reported that in their FEA and a natural mastication cycle study in implant abutment structures at different angles, the maximum stress can be minimized by changing the implant angle in the cervical region of the implant. Nowadays, in the construction of implant-supported restorations, especially in the aesthetic area of the dental arch, high-strength, all-ceramic materials are used. ${ }^{22}$ The mechanical properties of zirconia allowed them to use in posterior fixed partial prostheses and significantly reduce the thickness of the cores. $^{23}$

In a literature search there was no study evaluating implant-supported posterior restorations using zircon crowns with straight and angled abutments. In this study the stress distribution of a zircon-crown restoration that will be prepared by using angular and straight abutments in mandibular second-molar deficiency, under functional forces, stress over the zircon crown and environmental tissues of implant are evaluated by the FEA method.

\section{MATERIALS AND METHODS}

This study was designed to examine the tension occurring on the implant placed in the buccal direction using a 20-degree abutment and on the zircon crown due to the anatomical imperfections of the implant placement in the lower molar region. In the present study, the finite-element method (FEM) is used to find different stresses and strains caused by different angulated abutments of an implant prosthesis that is subjected to constant load.

\subsection{Creation of $3 D$ model}

In the present study, a 3D model of an implant prosthesis, which was used in place of a tooth, was generated using SLICER 4.11 Software. This software is creating a STL model from tomography results. It also supports different data formats like BRE, STL, PLY and VRML. In order to obtain a 3D model whose point cloud data (STL) were generated, Quick Surface Reconstruction and Digitized Shape Editor modules of CATIA V5R2015 software were utilized. The point cloud data transferred to the CATIA V5 software is in Stereo Lithography (STL) format. The number of points generated is 230077 .

A mesh model needs to be created between the points for a re-modeling over the point cloud. For this purpose, the mesh model is generated, with the help of the Mesh Building Wizard, based on the maximum and minimum length data between the dimensions of the mesh and the points. The structure of the mesh was designed so that

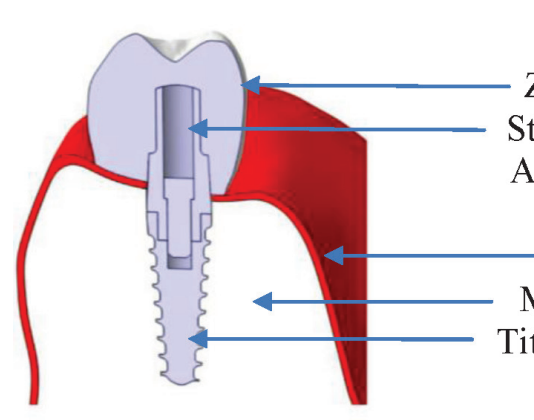

(a)

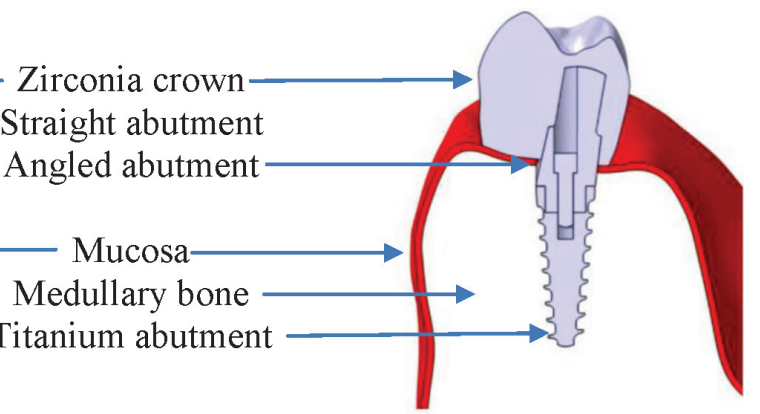

(b)

Figure 1: a) 0-deg 3d model cross-section, b) 20-deg 3d model cross-section 


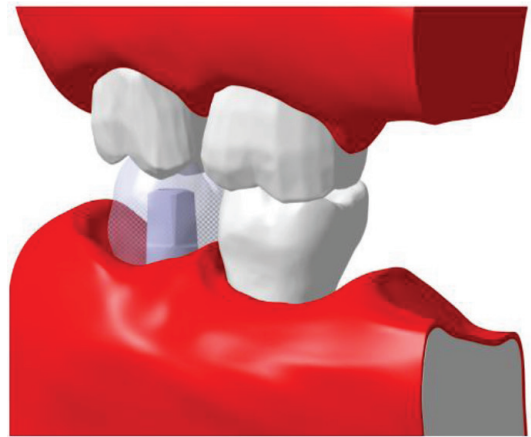

(a)

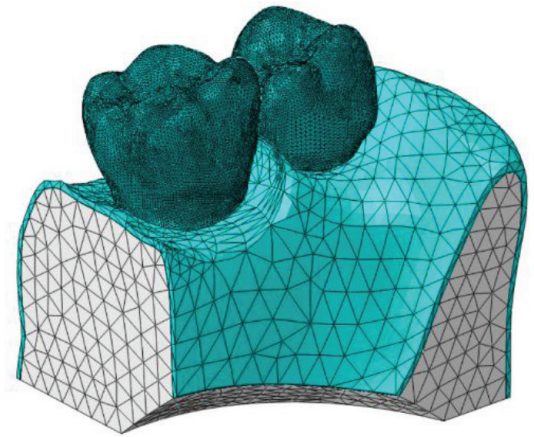

(b)

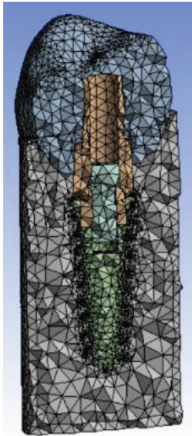

Figure 2: a) Relationship between maxillary and mandibular arches, b) 3D mesh model

the maximum dimension of the mesh was $1.5 \mathrm{~mm}$ and the maximum distance between the points was $0.1 \mathrm{~mm}$.

It is very important to minimize the amount of deviation between the 3D model generated and the point-cloud data. For this purpose, a deviation analysis needs to be conducted for all the surfaces generated through zone definitions. The deviation analysis is studied taking into account the dimension of the part, the running accuracy and the regional stability variables. The maximum allowable deviation for this model is $0.05 \mathrm{~mm}$. For this reason, an analysis was performed on every surface generated. The implant, abutment and crown models of which cross-sections are presented in Figure 1.

Table 1: Number of elements of all the constituent parts

\begin{tabular}{|l|c|c|}
\hline \multicolumn{1}{|c|}{ Model name } & Number of nodes & Number of elements \\
\hline Cortical bone & 146.245 & 96.882 \\
\hline Trabecular bone & 121.632 & 68.548 \\
\hline Gingiva & 135.227 & 88.167 \\
\hline Crown & 28.414 & 18.380 \\
\hline Cement & 6.358 & 3.241 \\
\hline Implant & 63.918 & 38.491 \\
\hline Abutment & 9.963 & 5.768 \\
\hline Abutment screw & 638 & 342 \\
\hline
\end{tabular}

\subsection{Computational analysis}

ANSYS V17.2 FEA software was used to determine the stress distribution on the implant. The 3D solid model obtained with CATIA V5 was transferred to ANSYS Design Modeller and a 3D solution mesh was created with Mesh Generation. The FEM is a numerical method that allows us to obtain information about the structure by dividing the structure into a finite number of small elements and by solving a finite number of equations instead of an infinite number of equations. For this reason, the established solution mesh is vital for the calculation result. An adaptive mesh is applied in the FEM. The total number of solution meshes used in the constituent parts is given in Table $\mathbf{1}$.

Two different FEAs were performed for the abutment geometry at $0^{\circ}$ and $20^{\circ}$ angles. The same boundary conditions were determined for all the solutions and a $250 \mathrm{~N}$ load was applied ${ }^{40}$ on the functional cusp in the vertical axis direction through the coating material on the implant placed on the lower-right second. However, the surface of the bone is fixed in all directions from the base. It is accepted that the implants are $100 \%$ bone-implant contact (100\% bone-implant contact). The following figure shows the boundary conditions used in a linear static analysis.

Static results were obtained for the two different abutment geometries using the ANSYS V17.2 FEA software. In the creation of the model, the lengths are given as $\mu \mathrm{m}$ units and the modulus of elasticity is given by $\mathrm{N} / \mu \mathrm{m}^{2}$ unit. In the model; the height of the crown is $7000 \mu \mathrm{m}$, the width of the crown is $5000 \mu \mathrm{m}$, the thickness of the adhesive is $50 \mu \mathrm{m}$ and the height of the implant is $4950 \mu \mathrm{m}$. The usability of the model was controlled by ensuring that the sum of the forces with astatic equilibrium is equal to zero (the resultant force is equal to zero).

Table 2: Properties of materials used in the FEA

\begin{tabular}{|c|c|c|c|c|}
\hline Model name & Material & Young's modulus (GPa) & Poisson's ratio $(u)$ & References \\
\hline Cortical bone & - & 18.6 & 0.30 & K. S. Lee at al. ${ }^{41}$ \\
\hline Trabecular Bbone & - & 13.7 & 0.30 & \\
\hline Gingiva & - & 10.0 & 0.40 & \\
\hline Crown & Zirconia & 205.0 & 0.19 & \\
\hline Cement & Resin adhesive cement & 18.6 & 0.28 & \\
\hline Abutment & Titanium (grade IV) & 110.0 & 0.35 & \\
\hline Implant & Titanium (grade IV) & 110.0 & 0.35 & \\
\hline Abutment screw & Titanium (grade IV) & 110.0 & 0.35 & \\
\hline
\end{tabular}




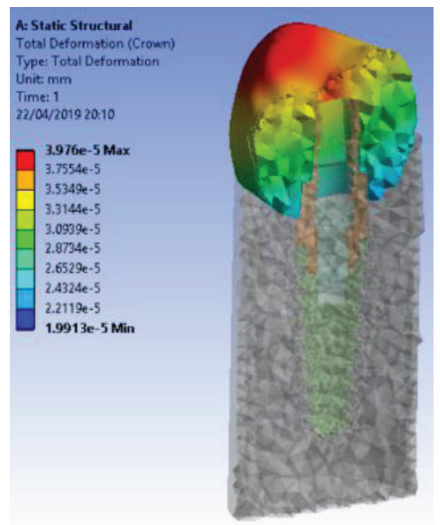

(a)

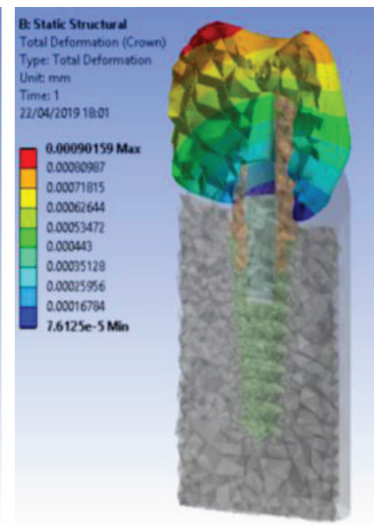

(b)
Figure 3: Total deformation on zirconia crown with: a) straight $0^{\circ}$, b) angled $2^{\circ}$

\section{RESULTS}

In Figure 3 a $250-\mathrm{N}$ load is applied on the crown surface in the directions of $Y$ and $Z$ axes and the total deformations on the crown are shown. When the deformation solutions formed on the crown are examined, it is observed that the solutions made in the model using an angled abutment give the lowest values.

Figure 4 shows the highest stresses on the abutment. It was seen that the highest stresses were on the tooth tops, which were the connection surface with the implant. Stresses in the straight and angled abutment models were determined at similar points. When the results were examined, it was revealed that the use of straight abutments provided the lowest stresses.

The lowest stresses on the implant were examined. It was observed that the lowest stresses were formed on the axial surface of the implant and the highest stresses were on the tooth surfaces with the abutment. It has been shown that the use of straight implants contributes to the lowest stresses.

When the von Misses stress distribution is shown in Figure 6, it is a very critical region because the highest stresses are at the junction of the crown and the adhesive cement layers and also on the outer surface as a geometric settlement. Considering the properties of the material, this stress distribution in general, the formation of cracks in the model and separation between layers can be estimated. When we look at the von Misses stresses, it

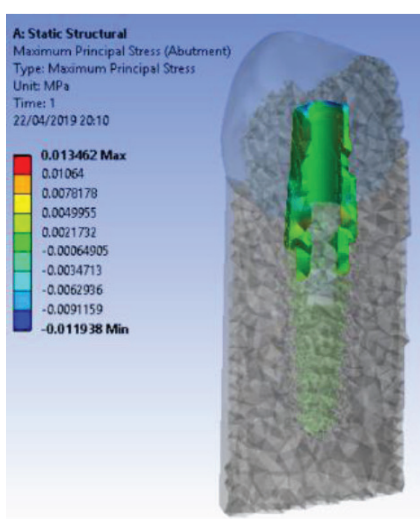

(a)

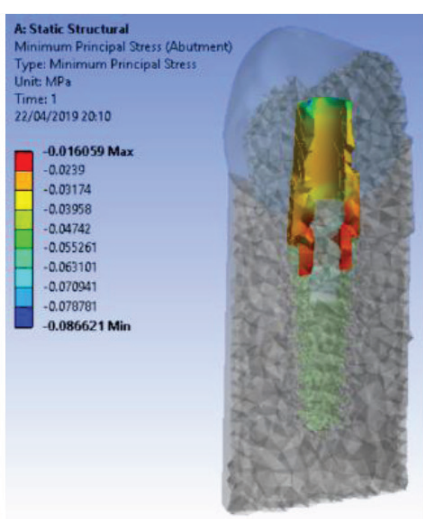

(b)

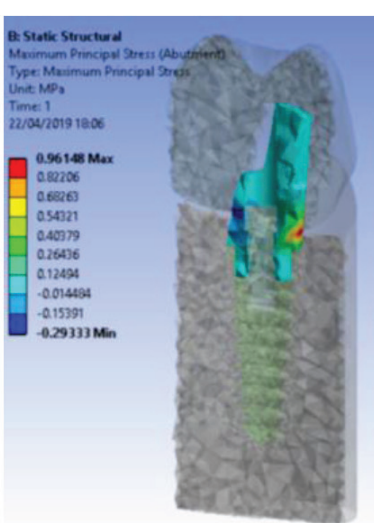

(c)

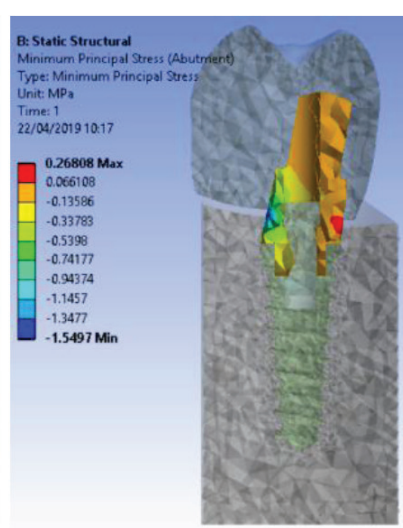

(d)

Figure 4: Maximum and minimum principal stress on the abutment with: a) straight $0^{\circ}$, b) angled $20^{\circ}$

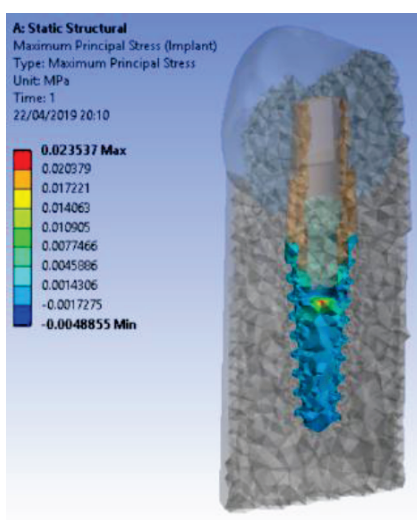

(a)

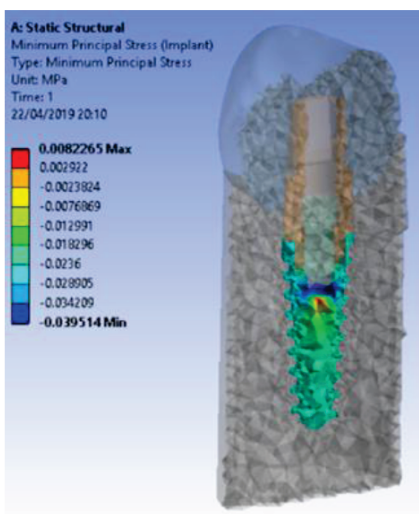

(b)

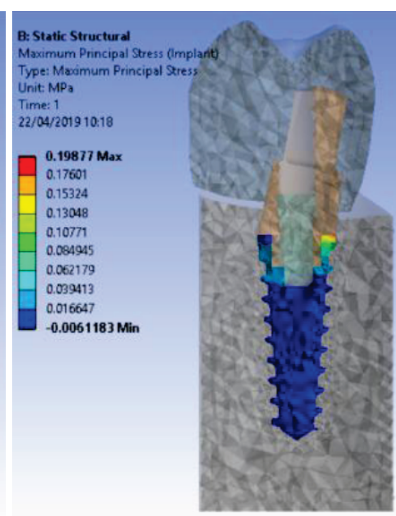

(c)

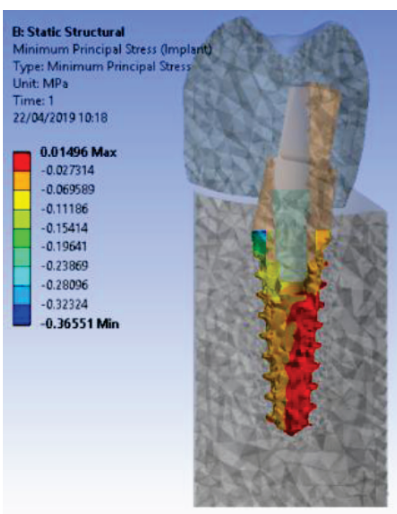

(d)

Figure 5: Maximum and minimum principal stresses on the implant with: a) straight $0^{\circ}$, b) angled $20^{\circ}$ 


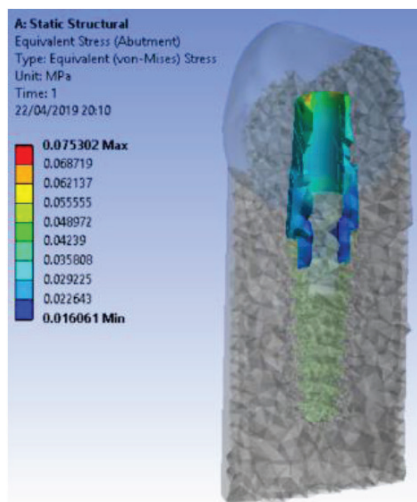

(a)

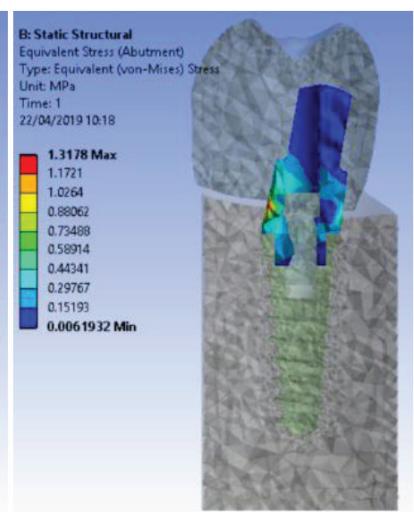

(b)

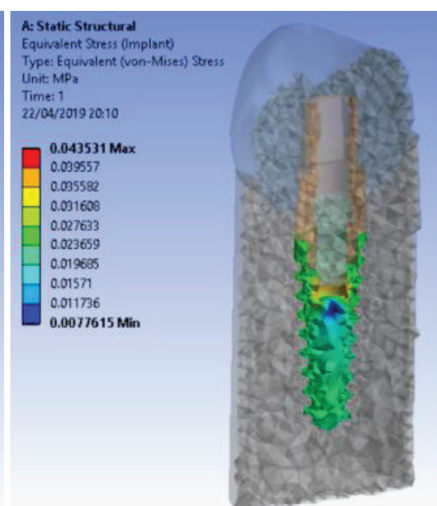

(c)

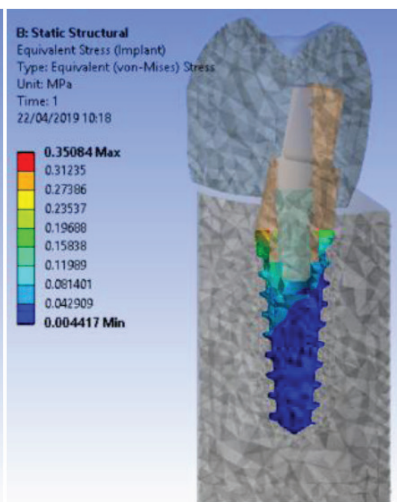

(d)

Figure 6: von Misses stress on abutment and implant with: a) straight $0^{\circ}$, b) angled $20^{\circ}$

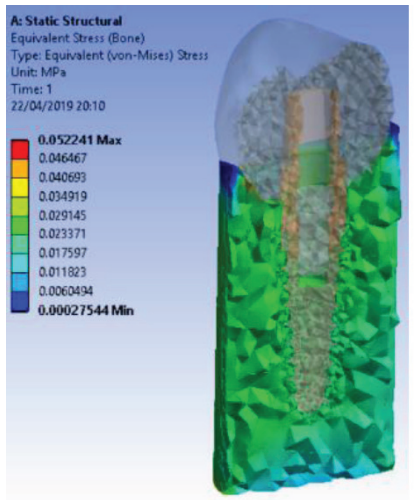

(a)

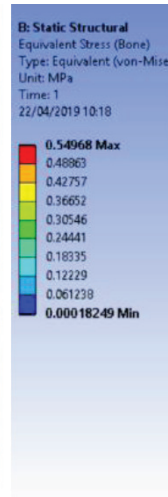

(b)
Figure 7: von Misses stress on bone: a) straight $0^{\circ}$, b) angled $20^{\circ}$

was determined that the use of straight implants showed better results than other applications (Figure 7).

\section{DISCUSSION}

There are three different ways in which stress analyses can be performed: analytical, experimental and computational. In fact the most important one is the computational, in which the stress analysis would seem to be the most natural way to approach this problem. With an increase in the computational power, the use of the FEM can help to simulate with a great accuracy the functioning of the human tooth. ${ }^{24}$

Numerical and experimental studies have shown that the increased abutment angle results in more stress on the prosthesis and surrounding bone than straight abutments. However, a prosthesis with angled abutments did not show a decrease in lifetime. There was no more bone loss than with straight abutments. ${ }^{25}$ There may also be anatomical reasons that prevent the implant's placement in a second molar region. Anatomical constraints sometimes require surgical positioning of the implants at angles that are not optimal for prosthetic restorations. The width, height, angle, presence of the bone undercut, the shape of the arch and the relationship between the jaws are the considerations for implant placement.

For example, there may be insufficient bone height or width to place an implant without the use of a bone graft, or the position of the inferior alveolar nerve may impede the placement of the second molar implant without performing bone augmentation. ${ }^{18}$ Another possibility of implant placement in this region is the use of angled implant abutments. There are angled abutments at specific separation angles; furthermore, a customized angled abutment can be prepared for an acceptable prosthesis treatment. ${ }^{26}$ Historically, the need to change the angle of the abutment has been understood as a result of the difference between the bone present for implant placement and the long axis of the planned restoration. However, there are concerns about the negative effects of non-axial forces on the survival of implants. ${ }^{27}$

The preferred inclination of implants is a common problem that can jeopardize the aesthetics and function of implant-supported fixed prostheses. ${ }^{28}$ The buccolingual folding of the mandibular posterior toothless region can affect the conditions of prosthetic loading, thus causing high-stress areas that can easily cause stress. ${ }^{29}$

A. Ellakwa et al. ${ }^{30}$ showed that using angled implants reduces the crown fracture resistance on the implant. The results of the present study demonstrate that when the deformation solutions formed on the crown are examined, it is observed that the solutions made in the model using an angled abutment give the lowest values. This result can be thought of as the imposition of implants on the buccal and the application of loads on the functional cusp.

X. A. Saab et al. ${ }^{31}$ showed the effect of the abutment angulation on the strain in the anterior maxilla by the FEA. There was no difference in the pattern of the strain distribution predicted using a straight or an angled abutment in the anterior maxilla. J. Cavallaro et al. ${ }^{25}$ and B. Rohit et al..$^{32}$ evaluated five abutment divergences $\left(0^{\circ}\right.$, $15^{\circ}, 25^{\circ}, 30^{\circ}$ and $35^{\circ}$ ). On the basis of available data in the literature, they concluded that though the com- 
pressive and tensile stresses generated through axial and oblique loading increase as the abutment angulation increases, they are within the tolerance limits of the bone.

Z. Arsalanloo et al. ${ }^{16}$ found that by increasing the abutment angulations, the amount of strain in the implant and cortical bone could be higher. T. Brosh et al. ${ }^{33}$ and T. Begg et al. ${ }^{34}$ also verified that vertical loads applied in angled abutments produced higher stresses at the coronal zone of the implant compared with straight abutments.

To avoid high stresses at that location, the implant should be planned to be subjected to vertical forces during function. ${ }^{35}$ There seems to be no difference in the survival of implants based on the use of angulated abutments ranging from $0^{\circ}$ to $45^{\circ}$. T. J. Balshi et al. ${ }^{36}$ have also demonstrated that the survival of implants loaded via 30-degree abutments is not significantly different from implants loaded via straight abutments. When the stresses on the abutments were examined, it was determined that the stresses occurred in the straight and angled abutment models at similar points. When the results were examined, it was revealed that the use of straight abutments provided the lowest stresses.

With the clinical loading of implants restored using angled abutments, lateral occlusal forces can increase. N. L. Clelland et al. ${ }^{37}$ found a statistically significant increase in the stress and strain with an increase in the abutment angulation when evaluating $0-^{\circ}, 15-^{\circ}$, and $20-^{\circ}$ abutments, but the principal strains were considered to be within the physiological zone for bone. R. Celletti et al. ${ }^{38}$ observed no adverse effect on the surrounding bone with straight or pre-angled abutments in monkeys. Based on a histological examination at 1 year after loading, excellent osseo-integration was reported.

In the present study, when the stresses on implants were examined, it was determined that the highest and lowest stress zones are at the same points. It has been shown that the use of straight implants contributes to the lowest stresses. Increases in the abutment angulation can increase the principle strains (compressive and tensile) in the bone around the implants, as shown by in-vitro strain-gauge studies. ${ }^{36}$

Whether or not a second molar should be replaced after its removal is debatable. The data indicated that replacing a second molar provides some increased masticatory performance, but first-molar occlusion facilitates a $90 \%$ chewing efficiency. It was concluded that after a patient/dentist discussion regarding second-molar replacement, it is the patient's preference that usually dictates the decision. ${ }^{39}$

\section{CONCLUSIONS}

Within the limitations of this study, the following conclusions can be drawn:

- The FEM is the nearest-possible method available today to simulate the oral cavity in vitro.
- FEA is a numerical method for addressing mechanical problems and it is a powerful contemporary research tool.

- FEA results have shown that the use of straight implants contributes to the lowest stresses.

- Similar to the literature, the selection of straight and angular abutments is very important for the balance of a distributed loading.

- This will continue to be studied due to the limitations of the tooth's anatomy.

\section{REFERENCES}

${ }^{1}$ H. Weber, C. Sukotjo, Does the type of implant prosthesis affect outcomes in the partially edentulous patient, International Journal of Oral Maxillofacial Implants, 22 (2007), 140-172

${ }^{2}$ L. Avivi-Arber, G. A. Zarb, International Journal of Oral \& Maxillofacial Implants, 11 (1996) 3, 311-321

${ }^{3}$ D. J. Witter, P. V. Elteren, A. F. Käyser, Signs and symptoms of mandibular dysfunction in shortened dental arches, Journal of Oral Rehabilitation, 15 (1988) 5, 413-420

${ }^{4}$ A. F. Kayser, Shortened dental arch: a therapeutic concept in reduced dentitions and certain high-risk groups, The International Journal of Periodontics \& Restorative Dentistry, 9 (1989) 6, 426-449

${ }^{5}$ G. Greenstein, B. Greenstein, J. Carpentieri, The Need to Replace a Missing Second Molar With a Dental Implant Restoration: Analysis of a Controversial, Compendium of Continuing Education in Dentistry, 39 (2018) 10, 686-693

${ }^{6}$ R. Himmel, R. Pilo, D. Assif, I. Aviv, The cantilever fixed partial denture-a literature review. The Journal of Prosthetic Dentistry, 67 (1992) 4, 484-487

${ }^{7}$ U. W. Jung, J. Y. Choi, C. Kim, C. Kyoo-Sung, C. Jung-Kui, K. Chong-Kwan, C. Seong-Ho, Evaluation of mandibular posterior single implants with two differentsurfaces: A 5-year comparative study. J. Periodontology, 79 (2008) 10, 1857-1863

${ }^{8}$ H. Weber, C. Sukotjo. Does the type of implant prosthesis affect outcomes in the partially edentulous patient, International Journal of Oral and Maxillofacial Implants, 22 (2007), 140-172

${ }^{9}$ E. Behnaz, M. Ramin, S. Abbasi, M. A. Pouya, F. Mahmood, The effect of implant angulation and splinting on stress distribution in implant body and supporting bone: A finite element analysis. European Journal of Dentistry, 9 (2015) 3, 311-318

${ }^{10}$ K. Moon-Sun, L. Jae-Kwan, C. Beom-Seok, U. Heung-Sik, Masticatory function following implants replacing a second molar, Journal of Periodontal \& Implant Science, 41 (2011) 2, 79-85

${ }^{11}$ D. A. Garber, U. C. Belser, Restoration-driven implant placement with restoration-generated site development, Compendium Continuing Education Dentistry, 16 (1995) 8, 798-802

${ }^{12}$ T. D. Taylor, U. Belser, R. Mericske-Stern, Prosthodontic considerations, Clinical Oral Implants Research, 11 (2000) 1, 101-107

${ }^{13}$ M. C. Cehreli, S. Sahin, Fabrication of a Dual-Purpose Surgical Template for Correct Labiopalatal Positioning of Dental Implants, The International Journal of Oral \& Maxillofacial Implants, 15 (2000) 2, 278-282

${ }^{14}$ N. L. Clelland, A. Gilat, The effect of abutment angulation on stress transfer for an implant, Journal of Prosthodontics, 1 (1992) 1, 24-28

${ }^{15}$ K. Akca, H. Iplikcioglu, Finite element stress analysis of the influence of staggered versus straight placement of dental implants, International Journal of Oral \& Maxillofacial Implants, 16 (2001) 5, 722-730

${ }^{16}$ Z. Arsalanloo, R. Telchi, K. G. Osgouie, A Three-Dimensional FEA of Implants to Investigate Effects of Angle Implantation Cases in Implants Success, International Journal of Bioscience, Biochemistry and Bioinformatics, 4 (2014) 4, 275-279 
${ }^{17}$ D. Buser, W. Martin, U. C. Belser, Optimizing esthetics for implant restorations in the anterior maxilla: anatomic and surgical considerations, International Journal Oral Maxillofacial Implants, 19 (2004), 43-61

${ }^{18}$ C. Misch, Prosthodontic considerations. Misch C, Contemporary Implant Denistry, St Louis:Mosby (1993),187-200

${ }^{19}$ K. Tian, J. Chen, L. Han, J. Yang, W. Huang, D. Wu, Angled abutment result in increased or decreased stress on surrounding bone of single unit dental implants: a finite element analysis, Medical Engineering \& Physics, 34 (2012) 10, 1526-1531

${ }^{20}$ N. L. Clelland, A. Gilat, The effect of abutment angulation on stres transfer for an implant, Journal of Prosthodontics, 1 (1992) 1, 24-28

${ }^{21}$ N. T. Iniyan, M. K, Dhananjay, D. S. Savio D. S. A. Lourenco, Pre-Operative Simulation Of Implant Angulation Effect On Mandibular Masticatory Stresses - A Finite Element Study, Procedia Engineering, 64 (2013), 815-824

${ }^{22}$ W. Att, T. Hoischen, T. Gerds, J. R. Strub, Marginal adaptation of all-ceramic crowns on implant abutments. Clinical Implant Dentistry and Related Research, 10 (2008) 4, 218-225

${ }^{23}$ I. Denry, J. R. Kelly, State of the art of zirconia for dental applications, Dental Materials, 24 (2008), 299-307

${ }^{24}$ A. Merdji, Stress analysis in single molar tooth, Materials Science and Engineering: Part C, 33 (2013) 2, 691-698

${ }^{25}$ J. Cavallaro, G. Greenstein, Angled implant abutments: a practical application of available knowledge, The Journal of the American Dental Association, 142 (2011) 2, 150-158

${ }^{26}$ C. M. Bruggenkate, F. Sutter, H. S. Oosterbeek, A. Schroeder, Indications for angled implants, Journal of Prosthetic Dentistry, 67 (1992), 85-93

${ }^{27}$ A. Sethi, T. Kaus, P. Sochor, The use of angulated abutments in implant dentistry: five-year clinical results of an ongoing prospective study, International Journal of Oral \& Maxillofacial Implants, 15 (2000) 6, 801-810

${ }^{28}$ S. Canay, N. Hersek, I. Akpinar, Z. Aşik, Comparison of stress distribution around vertical and angled implants with finite-element analysis, Quintessence International, 27 (1996) 9, 591-598

${ }^{29} \mathrm{~K}$. Akca, H. Iplikçioglu, Evaluation of the effect of the residual bone angulation on implant-supported fixed prosthesis in mandibular posterior edentulism part II: 3-D finite element stress analysis, Implant Dentistry, 10 (2001) 4, 238-245

${ }^{30}$ A. Ellakwa, T. Raj, S. Deeb, G. Ronaghi, F. E. Martin, I. Klineberg, Influence of implant abutment angulations on the fracture resistance of overlaying CAM-milled zirconia single crowns, Australian Dental Journal, 56 (2011) 2, 132-140
${ }^{31}$ X. E. Saab, J. A. Griggs, J. M. Powers, R. L. Engelmeier, Effect of abutment angulaiton on the strain on the bone around an implant in the anterior maxilla: A FEA Study, Journal of Prosthetic Dentistry, 97 (2007) 2, 85-92

${ }^{32}$ B. Rohit, A. Bhargavi, K. Dheeraj, A. Himanshu, A. Vishal, G. Minkle, Evaluation of stress patterns in bone around dental implant for different abutment angulations under axial and oblique loading: A finite element analysis, National Journal of Maxillofacial Surgery, 4 (2013)1, 46-51

${ }^{33}$ T. Brosh, R. Pilo, D. Sudai, The influence of abutment angulation on strains and stresses along the implant/bone interface: Comparison, Journal of Prosthetic Dentistry, 79 (1998) 3, 328-334

${ }^{34}$ T. Begg, G. A. Geerts, J. Gryzagoridis, Stress patterns around distal angled implants in the all-on-four concept configuration, International Journal of Oral and Maxillofacial Surgery, 24 (2009) 4, 663-671

${ }^{35}$ R. S. Wylie, A. A. Caputo, C. Alexandridis, S. Habaki, Effect of maxillary fixture and angulation on load transfer, Journal of Prosthodontics, 70 (1991), 1541

${ }^{36}$ T. J. Balshi, A. Ekfeldt, T. Stenberg, L. Vrielinck, Three-year evaluation of Brånemark implants connected to angulated abutments, Internation Journal Oral Maxillofacial Implants, 12 (1997), 52-58

${ }^{37}$ N. L. Clelland, A. Gilat, A. McGlumphy, W. Brantley, A photoelastic and strain gauge analysis of angled abutments for an implant system, International Journal Oral Maxillofacial Implants, 8 (1993), 541-548

${ }^{38}$ R. Celletti, C. H. Pameijer, G. Bracchetti, K. Donath, G. Persichetti, I. Visani, Histologic evaluation of osseointegrated implnats restored in nonaxial function occlusion with preangled abutments, Internatioanl Journal Periodontics Restorative Dentistry, 15 (1995), $563-573$

${ }^{39}$ G. Greenstein, B. Greenstain, J. Carpentier, The Need to Replace a Missing Second Molar With a Dental Implant Restoration: Analysis of a Controversial Issue, Compendium of Continuing Education in Dentistry, 39 (2018) 10, 686-693

${ }^{40}$ S. Y. Ertem, S. Uckan, U. A. Ozden, The Comparison of Angular and Curvilinear Marginal Mandibulectomy on Force Distribution with Three Dimensional Finite Element Analysis, Journal of CranioMaxillofacial Surgery, 41 (2013) 3, 54-58

${ }^{41}$ K. S. Lee, J. H. Shin, J. E. Kin, J. H. Kim, W. C. Lee, S. W. Shin, J. Y. Lee, Biomechanical Evaluation of a Tooth Restored with high performance polymer PEKK post core system: a $3 \mathrm{~d}$ finite element analysis, BioMed Research International, (2017), 1-9 